\section{COMPILATION OF PAPERS FOR USE BY POSTGRADUATE STUDENTS OF PSYCHIATRY}

Dear SiR,

The Clinical Tutors Sub-Committee, through the courtesy of John Wyeth and Brother, has prepared 350 copies of a compilation of selected papers in psychiatry for postgraduate students.

Volumes have been despatched to all psychiatric hospitals in the British Isles which have clinical tutors known to the Royal College of Psychiatrists. If any hospital with a tutor has by mischance not received a copy and wishes to have one it can be obtained free on application to the editorial office of the foumal, Chandos House, 2 Queen Anne Street, London, WIM gLE.

\section{B. M. BARRAclough.}

B. Heine.

MRC Clinical Psychiatry Unit,

Graylingwell Hospital,

Chichester,

Sussex.

\section{FORTHCOMING CONFERENCES}

International Conference on Alcoholism and Addiction

The Irish National Council on Alcoholism and the International Council on Alcohol and Addictions are organizing an International Conference on Alcoholism and Addiction, to be held in Dun Laoghaire, Dublin, Ireland, from 5-8 October, 197 I. Further information is available from: The Confer- ence Secretary, Irish National Council on Alcoholism, 19/20 Fleet Street, Dublin, 2.

Sixth International Meeting of Forensic Sciences

The Sixth International Meeting of Forensic Sciences will be held in Belfast from $21-26$ September, 1972. There will be a section on Forensic Psychiatry. Papers of not more than twenty minutes' length on any aspect of forensic psychiatry are invited, and authors are asked to submit titles and summaries of not more than 200 words by 31 October, 1971 . All papers will be published as abstracts but time may not permit all of them to be read. For further information about the Meeting, when published, apply to: The Secretariat, 6th International Meeting of Forensic Sciences, Institute of Pathology, Grosvenor Road, Belfast, Northern Ireland.

\section{Community Care and Psychiatry}

A Weekend Seminar on 'Community Care and Psychiatry', organized by a multi-disciplinary group in the Liverpool region, will be held at the Salisbury and McNair Halls of Residence, Liverpool University, from Friday evening, 24 September, to Sunday afternoon, 26 September, 1971. Speakers of national repute have agreed to take part, and there will be opportunites for informal discussion by Course participants.

The fully inclusive residential charge is $£ 10.00$; for non-residents, $£ 7.00$. A full programme will be published later, but bookings are now being accepted by the Group Secretary, Rainhill Hospital, Prescot, Lancs., L35 4PQ. 